\title{
Dissonância do turismo: por um (des)encontro habitante-visitante
}

\author{
Dissonance of tourism: for a (dis)encounter habitant-visitant \\ Disonacia del turismo: por un (des)encuentro habitante visitante \\ Marcelo Milito \\ Universidade Federal do Rio Grande do Norte (UFRN), \\ Brasil \\ marcelomilito@yahoo.com.br \\ Victor Hugo Silva \\ Universidade Federal do Rio Grande do Norte (UFRN), \\ Brasil \\ victor_sector7@hotmail.com \\ Wilker Nóbrega \\ Universidade Federal do Rio Grande do Norte (UFRN), \\ Brasil \\ wilkernobrega@yahoo.com.br
}

DOI: https://doi.org/10.18472/cvt.19n3.2019.1464
Redalyc: http://www.redalyc.org/articulo.oa?
id=115461709011

Recepción: 29 Julio 2017

Aprobación: 17 Abril 2019

\section{Resumo:}

O estudo tem como objetivo contribuir com o repensar da atividade turística ao tomar como eixo a dissonância no encontro entre visitantes e habitantes. Os objetivos específicos são caracterizar os debates teóricos e empíricos, na evolução do conceito de turismo, e resgatar a relação habitante-visitante como sua essência. . A presente investigação está embasada na literatura e na teoria com ênfase na discussão das anomalias e da busca pelo entendimento dessas contradições no turismo. Além dos questionamentos, criamse sugestões de propostas metodológicas, no que diz respeito à integração do fenômeno turístico à sociedade. O estudo avançou para compreensão de um modelo conceitual amplo, traz as inter-relações entre a atividade turística e o residente como ponto central dessa nova teoria.

Palavras-chave: Turismo, Habitantes, Visitantes, Encontro.

\section{Abstract:}

The objective of this study is to contribute to the rethinking of tourism activity, taking as its axis the dissonance of the encounter between visitors and habitants, with the specific objectives of characterizing the theoretical and empirical rebates in the evolution of the tourism concept and rescuing the habitant-visitor relationship as the essence of tourism. It is through literature, the discussion of the constant anomalies and the search for the understanding of these contradictions, that this research is based. In addition to the questions, suggestions are made for methodological proposals regarding the integration of the phenomenon into society. The study advanced to an understanding of a conceptual model, which in its completeness addresses as the axis the interrelations between the dynamics of the tourist activity and the residents.

KEYWORDS: Tourism, Habitantes, Visitors, Encounter.

\section{Resumen:}

El estudio tiene como objetivo contribuir con el repensar de la actividad turística tomando como eje la disonancia en el encuentro entre visitantes y habitantes, teniendo como objetivos específicos caracterizar los rebates teóricos y empíricos en la evolución del concepto de turismo y rescatar la relación habitante-visitante como la esencia del turismo. Es a través de la literatura, de la discusión de las constantes anomalías y de la búsqueda por el entendimiento de esas contradicciones, que se basa en esa investigación. Además de los cuestionamientos, se crean sugerencias de propuestas metodológicas, en lo que se refiere a la integración del fenómeno a la sociedad. De este modo, el estudio avanzó hacia la comprensión de un modelo conceptual, que en su completitud aborda como eje las interrelaciones entre las dinámicas de la actividad turística y el residente.

Palabras ClaVe: Turismo, Habitantes, Visitantes, Encuentro. 


\section{INTRODUÇÃO}

Em tempo de se tornar uma das maiores economias do mundo, e ser legitimado pelas principais organizações globais como a atividade prioritária do século XXI, o turismo e a hospitalidade já tinham sido preconizados como uma alternativa benéfica para a humanidade. Uma atividade pacificadora e transformadora, a partir da troca e do encontro com um outro que valoriza o meio sociocultural e ambiental, além de possibilitar o desenvolvimento econômico local. Transcorrida uma década e meia do novo milênio, o turismo realmente tornou-se um dos maiores mercados da atualidade, mas com muitos pontos destoantes a serem repensados. As arenas de discussão teóricas e empíricas apresentam anomalias, que vão desde prejuízos socioculturais, ambientais e econômicos locais até a dissociação de diálogo entre o saber técnico/empírico e acadêmico/ teórico. Não existe consenso na discussão conceitual do que é o turismo. E o mercado esbarra no crescente número de comunidades que limitam o recebimento de turistas.

Jafari (1994) sustenta que o pensamento sobre o turismo passou por três fases: a primeira, a surgir no pós guerra, é da atividade turística como essencialmente benéfica e uma promissora alternativa de sustentabilidade global; a segunda, que surgiu em meados da década de 1970 com estudos sócioantropológicos, contestando a legitimidade da atividade turística como essencialmente benéfica, apontando sérios malefícios na prática; e por fim, a partir da década de 1990, surge, por parte da academia seguida da sociedade e organizações globais, uma tentativa de ponderar as vantagens e desvantagens da atividade turística e as formas adaptadas de gestão, que mitiguem os impactos negativos e fomentem os impactos positivos, (re)encontrando a benesse do turismo.

Em uma rápida visão das rupturas de superfície do turismo a serem readaptadas, tanto pela variedade como pela profundidade, seria sintomática uma dissonância estrutural. A começar pela profunda dissociação entre teoria e prática do turismo, já detectado por Fúster (1978), a complexa multiplicidade de saberes associados ao turismo, como uma possibilidade e também entrave do saber turístico (JAFARI, 1981), os modelos de turismo que cristalizam o abismo entre o campo teórico e empírico do turismo (TRIBE, 1997), endossado em 2015 por Jafar Jafari, durante o T-fórum em Nápoles, ao acrescentar a tendência de fragmentação das graduações em turismo por cursos técnicos específicos. Como fato tangível dessa desagregação, o Ministério Brasileiro da Educação (2015) aponta, nos últimos sete anos, o número de cursos de graduação em turismo vem caindo pela metade, sendo substituído paulatinamente por cursos técnicos (como, por exemplo, nos setores da hotelaria, eventos, gastronomia, agências de viagem e guia de turismo).

"Nesse esfacelamento acadêmico, as clássicas discussões entre teóricos na área sobre "o que é turismo?” e “seria o turismo uma ciência?” (SESSA 1983 vs GRAY 1984),que poderiam ser consideradas o ápice das fissuras teóricas, ficam ofuscadas por esses novos eemergentes problemas nevrálgicos.

Discrepância acentuada, quando lembramos que o turismo é a maior atividade econômica da atualidade, que foi da inexistência ao exponencial crescimento, superando, em poucas décadas, as economias consolidadas do setor do petróleo e do automobilismo (OMT, 2000). Difícil entender como, em um mundo tecnológico e mercantil existem tantos abismos no saber da atividade, que segundo a Organização das Nações Unidas, seria a atividade prioritária do século XXI. Declarada prioritária não só pela pujança econômica, mas principalmente pelo poder de integração com as dimensões socioambientais, rumo aos objetivos humanitários do milênio, discurso que vêm sendo contestado, com contundência, por diversos atores do setor.

Justamente nesse ponto é que se encontra, nesse condensado de anomalias, o ponto central para repensar toda a atividade turística. A fase de crítica ao turismo surgiu exatamente da contestação dessa essência benéfica e sustentável, segundo Barreto (2004), tendo como ícones autores como De Kadt, com a obra "Turismo: passaporte para o desenvolvimento" e Doxey (1975), na criação de um modelo de irritabilidade dos residentes frente aos turistas e Krippendorf (2009), com experiências empíricas como agente de mercado, na qual apontaram decisivos impactos negativos, ao ponto de abrir fendas, que essa nova fase de adaptação ainda não 
logrou restaurar. Isso porque a percepção de impactos negativos do turismo transpassou a análise acadêmica e vem chegando ao senso comum, a ponto de comunidades residentes em destinos receptores demostrarem hostilidade aos turistas/visitantes (MILITO, 2013).

Fato social que, caso se concretize, fundirá definitivamente o discurso benéfico do turismo, emigrará a atividade para apenas mais um nicho do mercado global e declarar-se-á guerra ao bem-receber público no destino, implicando diretamente na imagem hospitaleira vendida e no apoio da população residente aos investimentos públicos no setor.

Milito, Marques Júnior e Alexandre (2013) assinalam as pesquisas que versam sobre o posicionamento do residente frente ao turismo, como uma constante nas publicaçóes nacionais e internacionais, tanto abordagens qualitativas, com preponderância dos estudos sócio-antropológicos, quanto abordagens quantitativas com preponderância dos estudos sócio-psicológicos. Kuhn (2006) indica, como um processo prévio da quebra do paradigma, o crescente foco da comunidade científica nostemas que circundam a anormalidade detectada, seguido da criação de novas teorias (passo atual dos estudos em turismo)que, conforme publicadas e aceitas pela comunidade científica, melhor respondem os problemas vigentes,

Nessa perspectiva emergente, o presente estudo tem como objetivo contribuir com o repensar da atividade turística tomando como eixo a dissonância no encontro entre visitantes e habitantes.

\section{DISSONÂNCIAS DO TURISMO}

Nos caminhos do saber explicitado por Foucault (2000) como "arqueologia do saber", surge um tipo de investigação que se preocupa em escavar o solo que deu origem a certos tipos de saberes. Não se busca uma arquitetura de conceitos e introduzir mais uma camada no mesmo edifício dedutivo rumo a perfeição, tenta-se analisar o jogo de seus aparecimentos e de sua dispersão (FOUCAULT, 1989). Nesse processo de análise das distorções que começa o resgate dos significados do turismo, talvez em algum momento perdido e ressignificado.

\subsection{Dissonância Empírica do Turismo}

O turismo como mercado estratégico tornou-se fundamental no plano de desenvolvimento dos principais organismos globais e nas políticas públicas governamentais, ainda mais quando aliado ao discurso da sustentabilidade. Sendo que os desdobramentos dessa atividade, e suas expectativas, estão sendo seriamente questionados para além do campo acadêmico.

Em 2 de outubro de 2009, na sede do Comitê Olímpico Internacional em Copenhagen, o presidente dos Estados Unidos da América e o presidente do Brasil (junto com toda uma comitiva nacional) duelaram publicamente para captar os Jogos Olímpicos 2016. O Brasil venceu, endossando a política nacional de turismo (BRASIL, 2010) explicitamente embasada em sediar megaeventos. Sendo que essa medida, que vinha aparecendo como contentamento geral, apresentou conflitoscomo mostra o quadro 1, os exemplos de redes físicas e virtuais das comunidades sedes, esboçando descontentamento com essa política de turismo.: 
Quadro 1 - Expressões do descontentamento público com megaeventos no Brasil

\begin{tabular}{|c|c|c|}
\hline $\begin{array}{l}\text { Pichação pública veiculada pela } \\
\text { https://periodismoturistico,word } \\
\text { press,com/2014/09/07/298L. } \\
\text { Imagem anônima tornou-se } \\
\text { marca internacional do rechaço } \\
\text { global que o turismo vem } \\
\text { sofrendo pelas comunidades } \\
\text { residentes. A emblemática e } \\
\text { turistica estátua do Cristo } \\
\text { Redentor, que é comumente } \\
\text { representada pelos acolhedores } \\
\text { braços abertos, aqui está em } \\
\text { preto e precedidos dos dizeres } \\
\text { traduzidos: "Turista, vá para } \\
\text { casa!!" }\end{array}$ & $\begin{array}{l}\text { Pichação pública veiculada pela } \\
\text { comunidade virtual "anti-copa", criada } \\
\text { em } 2013 \text { para congregar manifestantes e } \\
\text { manifestações, que se mantem com } \\
\text { finalidade de manter a cobrança no pós } \\
\text { evento. A imagem é auto-legendada e } \\
\text { explicita o mascote do evento indagando } \\
\text { sobre os problemas sociais e locais. É a } \\
\text { comunidade virtual, desse gênero do } \\
\text { facebook, com maior representatividade, } \\
\text { um total de } 23.372 \text { curtidas na página. } \\
\text { https://www.facebook.com/contracopa/ti } \\
\text { meline. }\end{array}$ & $\begin{array}{l}\text { Ilustração presente na foto de } \\
\text { capa da comunidade virtual "anti- } \\
\text { olimpiada", criada em } 2013 \text { para } \\
\text { congregar manifestantes e } \\
\text { manifestações. Retrata, uma vez } \\
\text { mais o emblemático braço aberto, } \\
\text { mas aqui voltado para trás, como } \\
\text { se estivesse tentando esconder os } \\
\text { problemas sociais retratados ao } \\
\text { fundo. } \\
\text { https://www.facebook.com/Protes } \\
\text { toContraRealizacaoDasOlimpiada } \\
\text { s/?fref-ts }\end{array}$ \\
\hline
\end{tabular}

Fonte: Elaboração própria a partir dos acessos supracitados em 16/05/16.

O Brasil, por captar e sediar em um curto espaço de tempo os maiores megaeventos da atualidade, ganha destaque, mas o posicionamento de aversão ao turismo e megaeventos (esse como o ápice moderno do desdobramento turístico) também está refletido em exemplos internacionais. Na Suécia, a prefeitura decidiu, publicamente em janeiro de 2014, voltar atrás da candidatura olímpica proposta em novembro de 2013, e não mais concorrer à disputa de sede dos Jogos Olímpicos de Inverno de 2022 alegando que priorizará a construção de moradias sociais para os autóctones. Um marco efetivo da ruptura na convergência da essência benéfica do turismo e megaeventos.

A negatividade dos impactos do turismo foi inicialmente abordada pelos estudos críticos sócioantropológicos (BARRETO, 2004), sendo que, nos recentes estudos sobre a percepção da comunidade residente, Almeida-García et al. (2016), Milito (2013) e Huh e Vogt (2008) convergem nos resultados de correlação entre faixa etária e apoio ao turismo, na qual as novas gerações estão cada vez mais conscientes dos impactos sócioambientais negativos da atividade, assim, é clara a tendência popular de rejeição da concepção benéfica do turismo. Hoje, essa discussão ganha imagética representação contemporânea nas artes, ofício ímpar de representação crítica da realidade observada: 
Quadro 2 - Pinturas do artista Pawel Kuczynski referente ao turismo

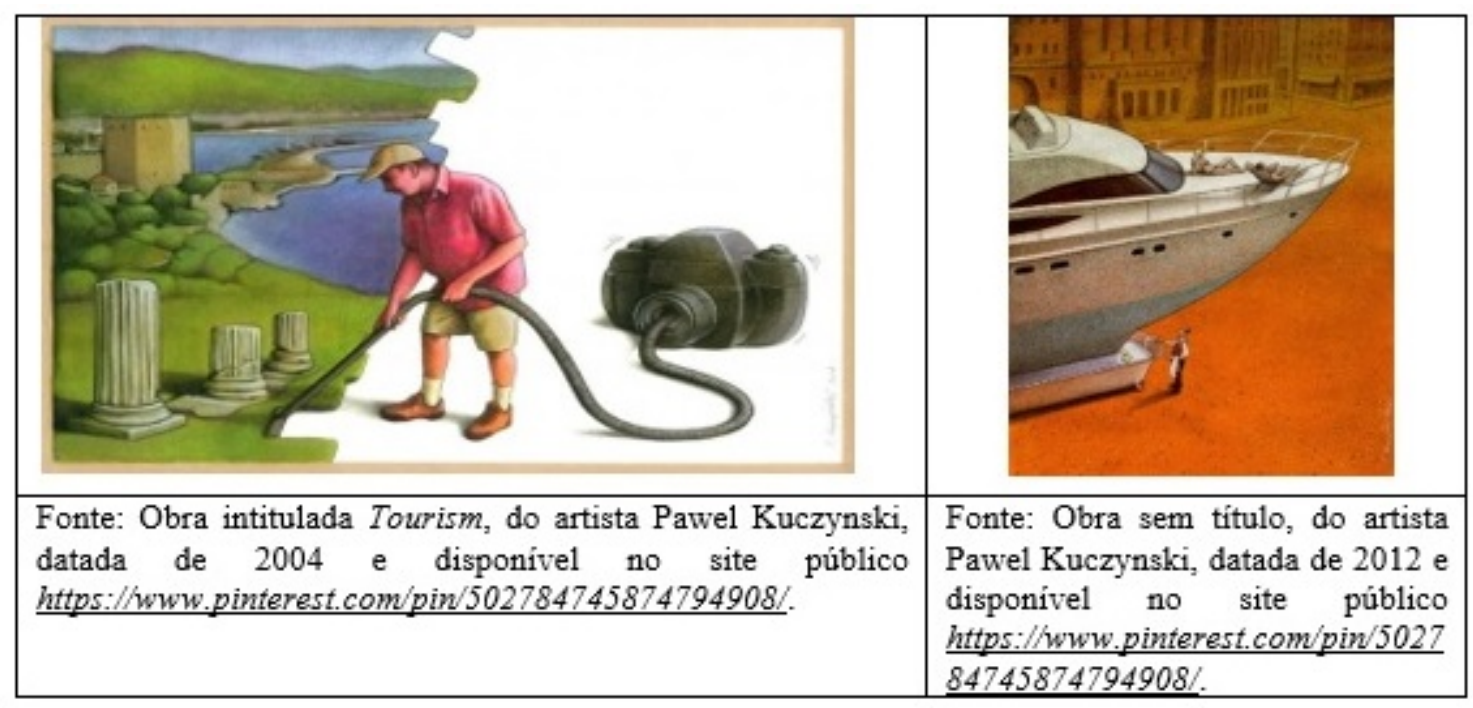

Fonte: Elaboração própria a partir dos acessos supracitados em 16/05/16.

A primeira ilustração, com título de referência direta ao turismo, aponta o turista como degradador direto do espaço físico e cultural, com uma visão similar ao pensamento crítico exposto por Cohen (1988), na qual o sujeito turista é o grande gerador das mazelas do turismo em si, consolidando essa como prática humana geralmente degradadora e prejudicial. A segunda ilustração, apesar de uma identificação mais subjetiva ao turismo, remete ao pensamento crítico de MacCannell (2003), na qual o atrativo turístico em si (aqui em forma de um iate de luxo) é um problema, personificando a submissão do trabalhador local (aqui representado por um garçom) que vive em uma realidade (escassa e árida) distinta da que ele produz (um ilusório e simbológico turismo de lazer e luxo).

Lembrando que a hospitalidade da população residente é comercialmente necessária, pois entra como o fator mais citado nos estudos de propagação de imagem dos destinos turísticos (GALLARZA et al. 2002). Como exemplo tem-se a pesquisa realizada sobre a percepção dos estrangeiros que vieram para a Copa do mundo no Brasil (Instituto de pesquisa Data folha, 2014), na qual a hospitalidade do povo brasileiro foi citada como a melhor parte da visita, suplantando os quesitos de qualidade/quantidade das atraçóes turísticas, mesmo tendo o motivo principal da visita uma atração específica, um megaevento.

Nesse embate é que se entranha às questões conceituais, pontuando, em um primeiro momento, o posicionamento do órgão oficial de turismo, que legitima e apoia o desenvolvimento turístico mundial, em constante parceria com a organização das nações unidas. A OMT foi fundada em 1970, apesar de seu embrião ter se iniciado no Primeiro Congresso Internacional de Associações Oficiais de Tráfego Turístico, celebrado em Haia, maio de 1925, desde sua criação, apesar de ser o órgão oficial de turismo, sempre deixou claro que a centralidade de suas atividades é regulamentar e fazer estatísticas técnicas/operativas do deslocamento de turistas, esquivando-se da responsabilidade conceitual do termo (PAKMAN, 2014). Esse posicionamento é observado no histórico de conceituações de turismo, resumidas no quadro abaixo. 
Quadro 3 - Histórico das definições de Turismo pela OMT

\begin{tabular}{|l|l|}
\hline Ano & Definição \\
\hline 1937 & $\begin{array}{l}\text { Turista internacional: Toda pessoa que viaja, por um periodo de } 24 \text { horas } \\
\text { ou mais, para um pais diferente daquele de sua residência habitual. (OMT } \\
\text { ainda como parte da Liga das naçóes Unidas). }\end{array}$ \\
\hline 1963 & $\begin{array}{l}\text { Turismo: Atividade desenvolvida por uma pessoa que visita um país } \\
\text { diferente daquele de sua residência habitual, com fins distintos do de } \\
\text { exercer uma ocupação remunerada, e por um periodo de tempo de pelo } \\
\text { menos } 24 \text { horas. (OMT ainda como parte da Organização das Naçôes } \\
\text { Unidas). }\end{array}$ \\
\hline 1991 & $\begin{array}{l}\text { O turismo compreende as atividades realizadas pelas pessoas durante suas } \\
\text { viagens a e estadias em lugares diferentes de seu entorno habitual, por um } \\
\text { período de tempo consecutivo inferior a um ano, tendo em vista lazer, } \\
\text { negócios ou outros motivos. }\end{array}$ \\
\hline 1999 & $\begin{array}{l}\text { O turismo compreende as atividades realizadas pelas pessoas durante suas } \\
\text { viagens a e estadias em lugares diferentes de seu entorno habitual, por um } \\
\text { periodo de tempo consecutivo inferior a um ano, tendo em vista lazer, } \\
\text { negócios ou outros motivos não relacionados ao exercício de uma } \\
\text { atividade remunerada no lugar visitado. }\end{array}$ \\
\hline 2008 & $\begin{array}{l}\text { O turismo é um fenômeno social, cultural e econômico, que envolve o } \\
\text { movimento de pessoas para lugares fora de seu local de residência } \\
\text { habitual. }\end{array}$ \\
\hline 2008 & $\begin{array}{l}\text { O turismo é um fenômeno social, cultural e econômico, que envolve o } \\
\text { movimento de pessoas para lugares fora do seu local de residência } \\
\text { habitual, geralmente por prazer. (essa como uma extensão da anterior). }\end{array}$ \\
\hline
\end{tabular}

Fonte: Elaboração a partir de Pakman, 2014.

Regressando um pouco mais, nota-se que a própria OMT, para formular seus preceitos, traz alguns teóricos para a discussão, conforme mostra a seguir.

Quadro 4 - Conceitos teóricos de turismo elucidados pela OMT

\begin{tabular}{|l|l|l|}
\hline Ano & Autor & Definição \\
\hline 1942 & $\begin{array}{l}\text { Hunziker } \\
\text { e Krapft }\end{array}$ & $\begin{array}{l}\text { Turismo é "A soma de fenômenos e de relações que surgem das } \\
\text { viagens e das instancias dos não residentes, desde que não } \\
\text { estejam ligados a uma residência permanente nem uma } \\
\text { atividade remunerada". }\end{array}$ \\
\hline 1981 & $\begin{array}{l}\text { Burkat e } \\
\text { Medlik }\end{array}$ & $\begin{array}{l}\text { Turismo é "Os deslocamentos curtos e temporais das pessoas } \\
\text { para destinos fora do lugar de residência e de trabalho e as } \\
\text { atividades empreendidas durante a estada nesses destinos". }\end{array}$ \\
\hline 1982 & $\begin{array}{l}\text { Mathieson } \\
\text { e Wall }\end{array}$ & $\begin{array}{l}\text { Turismo é "o movimento provisório das pessoas, por períodos } \\
\text { inferiores a um ano, para destinos fora do lugar de residência e } \\
\text { de trabalho, as atividades empreendidas durante a estada e as } \\
\text { facilidades são criadas para satisfazer as necessidades dos } \\
\text { turistas". }\end{array}$ \\
\hline 1994 & OMT & $\begin{array}{l}\text { O turismo compreende as atividades realizadas pelas pessoas } \\
\text { durante suas viagens a e estadias em lugares diferentes de seu } \\
\text { entorno habitual, por um periodo de tempo consecutivo inferior } \\
\text { a um ano, com finalidade de lazer, negócios ou outros. }\end{array}$ \\
\hline
\end{tabular}

Fonte: Elaboração própria a partir de OMT (2001, páginas 37 e 38)

As definições tidas como teóricas pela OMT, na qual a mesma incluiu sua definição como a última e a usada para todo desdobramento sistêmico da atividade turística, foi elaborada em torno de uma evolução linear, na qual cada uma apresenta pontos a serem melhorados. A definição de Hunziker e Krapft (1942) foi entendida como demasiada abstrata, principalmente pela amplitude do termo "fenômeno" (OMT, 2001), sendo que, nos últimos anos, a própria OMT passou a usar esse termo, como aponta o quadro 2. A definição de Burkat 
e Medlik (1981) também é criticada por uso de outro termo vago "deslocamento curto". Na definição de Mathieson e Wall (1982), a OMT encontra abrigo e fazem elogio enfático, usando como fundamento da sua definição e seus desdobramentos:

“Como se pode observar, destaca o caráter temporário da atividade turística ao introduzir o termo "período inferior há um ano". Também introduzem duas importantes inovações: de um lado a perspectiva da oferta quando mencionam "facilidades criadas", de outro, introduzem na definição o fundamento de toda atividade turística: a satisfação dos turistas/clientes (OMT, 2001, pg 38, grifo próprio)".

Fragmentado o tempo (menos de um ano) e a forma de transformação do espaço (satisfação das necessidades dos turistas/clientes), a OMT assume o foco da medição e direciona o olhar, mesmo tendo admitido a natureza complexa da atividade, reforça a necessidade de padronizar as estatísticas e normatiza oficialmente o sistema no grifado viés supracitado.

Dos 20 capítulos da obra de "introdução ao turismo" da OMT (2001), dois (ou seja, 10\%) trata dos impactos socioambientais locais, inclusive, de forma passiva, não tratando como encontro, mas sim, como impacto a ser recebido, sem o teor da troca. Mas reconhece a dissonância empírica, admitindo os impactos negativos, e clama por um turismo mais sustentável.

Vale salientar, que se alia aqui, a admissão por parte da OMT, mesmo que tratado como ad hoc, da dissonância teórica/conceitual com a empírica, respectivamente explicitadas no segundo capítulo (lembrando que o primeiro capítulo da obra não foi conceitual, somente avultou o poder econômico da atividade) e, nos capítulos 12 e 13, dos pontos positivos e negativos da atividade sobre espaço geográfico visitado.

Inclusive, a obra de referência da OMT supracitada possui inconteste similitude aos manuais administrativos empresariais, em que os impactos socioambientais são uma pequena parte dos riscos a serem gerenciados, tendo abordagens como "forma de venda", "marketing" e "competitividade" significante mais espaço na obra, tal semelhança não poderia ser diferente quando "o fundamento de toda atividade turística é a satisfação dos turistas/clientes (OMT, 2001, pg 38)". Assim, o habitante e seu habitat passam a ser reféns do visitante e do seu poder de mercado.

Mesmo assim, o próprio Conselho Chefe da OMT, em março de 2016, emitiu no informe oficial (CE $103 / 3$ d) que 2017, ano internacional do "turismo desenvolvimento do sustentável", lembrou ainda que 2002 foi o ano internacional do "Eco Turismo" e em 1967, o ano do "turismo como passaporte para a paz". Junto com a ONU, para alcançar os objetivos do milênio, a OMT hoje busca captar constantemente casos de sucesso no turismo sustentável e financia atividades desse gênero. No entanto, esse constante empenho aliado ao tratamento ad hoc, na visão de Kuhn (2006), é sintoma de preocupação com uma fissura de potencial revolucionário. Relembrar o turismo como veículo da paz (1967) é lembrar-se de um tempo em que o turismo era tido comumente como esperança social (o que transpassaria o viés comercial).

Entender-se-ia ainda a última conceituação da OMT (a de 2008, conforme quadro 2)que ressuscitou o termo, antes condenado, "fenômeno" e optou pelo uso da palavra "social, etrocessos talvez necessários que, a partir da visão pretendida, seriam o caminho para harmonizar as dissonâncias. Morin (2000) propõe uma lógica de desconstrução de fronteiras limitantes, (re)estabelecendo os núcleos ao invés de valorizar as barreiras.

Para tal, seguimos a proposição de resgatar o núcleo do turismo, ao entender que o normatizado pela OMT ("o fundamento de toda atividade turística é a satisfação dos turistas/clientes") está limitando uma possível função humana turística (que a própria ONU e OMT buscam), indo rumo aos pensamentos teóricos formados do turismo para além dos convencionados e destacados pela OMT, em busca de novos olhares com novas possibilidades. 


\subsection{Dissonância Teórica do Turismo}

Luis Fernadez Fuster (1978) em sua obra “Teoría y Técnica del Turismo" é reconhecido por ser um dos primeiros autores em turismo em pontuar uma revisão abrangente dos conceitos de turismo até o momento dispersos, possibilitando um caminho arqueológico a prosseguir, no presente estudo.

De maneira geral, os problemas levantados remontam às angústias de Fuster em 1978. O autor confirma o posicionamento de que o turismo tem paradoxos para resolver nos campos teórico (é ciência ou não), empírico (é social ou econômico) e econômico, uma vez que a economia vinha se tornando a maior entidade, não só porque surgiu como estudo na escola de economia de Berlin, mas pela sua força institucional em um mundo cada vez mais tendencioso ao mercantilismo global, sendo que o autor nega a medula puramente econômica do turismo. Ainda salienta a sua complexidade e multifacetada natureza, ainda em um período em que os estudos da complexidade não estavam aceitos como na atualidade.

Especificamente sobre o conceito de turismo, o referido autor resgata as primeiras definições teóricas de turismo, justamente antes dos conceitos expostos da OMT (2001) que pontuou somente a partir de Krapft (quadro 4), e remonta os primeiros entendimentos acadêmicos de turismo pela escola de economia de Berlin.

Quadro 5 - Primeiras definições teóricas de turismo pela escola Berlinense

\begin{tabular}{|l|l|l|}
\hline Ano & Autor & Definição \\
\hline 1929 & Glucksmann & $\begin{array}{l}\text { Um vencimento do espaço por pessoas que afluema } \\
\text { um lugar onde não possuem residência fixa. }\end{array}$ \\
\hline $1929 / 30$ & Schwink & $\begin{array}{l}\text { Movimento de pessoas que abandonam } \\
\text { temporariamente o lugar de sua residência permanente } \\
\text { por qualquer motivo relacionado ao espirito, corpo ou } \\
\text { profissão. }\end{array}$ \\
\hline 1930 & Borman & $\begin{array}{l}\text { Conjunto de viajantes cujo objetivo é o prazer ou por } \\
\text { motivos comerciais ou profissionais ou outros } \\
\text { análogos, e durante o qual é ausente da residência } \\
\text { habitual temporal. Não são turistas aquelas viagens } \\
\text { realizadas para transladar-se ao trabalho. }\end{array}$ \\
\hline 1939 & Glucksmann & $\begin{array}{l}\text { Soma das relaçôes existentes entre as pessoas que se } \\
\text { encontram passageiramente em um lugar de instancia } \\
\text { e os naturais daquele lugar. }\end{array}$ \\
\hline $1939^{*}$ & Benscheidt & $\begin{array}{l}\text { Conjunto de relações pacíficas de viajantes que ficam } \\
\text { num lugar, as pessoas ali domiciliadas e os naturais } \\
\text { daquele lugar. }\end{array}$ \\
\hline 1942 & Troisi & $\begin{array}{l}\text { Conjunto de translados temporais de pessoas, } \\
\text { originados por necessidades de repouso, de cura, } \\
\text { espiritualidade ou interesse. }\end{array}$ \\
\hline $1942^{*}$ & Gautier & $\begin{array}{l}\text { Conjunto de fenômenos econômicos e sociais } \\
\text { originados pelas viagens. }\end{array}$ \\
\hline 1942 & $\begin{array}{l}\text { Hunziker e } \\
\text { Krapft }\end{array}$ & $\begin{array}{l}\text { Conjunto de relações e fenômenos produzidos pelo } \\
\text { deslocamento e permanência de pessoas fora do seu } \\
\text { lugar de domicilio, desde que não estejam ligados a } \\
\text { uma residência permanente nem uma atividade } \\
\text { lucrativa. }\end{array}$ \\
\hline
\end{tabular}

Fonte: Elaboração e tradução própriaa partir de Fuster $(1978)$ *anos aproximados pelo contexto exposto pelo autor.

Fuster (1978), ao fazer essa reconstrução conceitual de turismo, a partir da escola Berlinense, não por menos, finaliza anunciando Krapft. Descrevendo esse autor como: "el tratadista más brillante que ha tenido hasta la fecha dela teoría y técnica del turismo (FUSTER, pg.54)”. Um grande entusiasta do turismo que levantou a bandeira dessa atividade e teve atuações na criação de institutos de pesquisa, de políticas públicas e nos órgãos globais de turismo, morreu no ano de $1963 \mathrm{em}$ um acidente aéreo indo para uma conferência da ONU sobre turismo. 
Observa-se ainda que, o fenômeno turístico foi tratado academicamente em seu início, como o entorno do deslocamento humano para fora do entorno habitual. Referindo-se imediatamente ao teor etimológico da palavra "Turismo", da mesma raiz de palavras como "torcido", "tornado", "retorno" e "turno", trata-se do giro em torno do próprio eixo, o processo de ir e voltar. Oriundo do latim "tornare", mas comumente utilizado pela Inglaterra, a partir do século XVII, inclusive em dicionários da época, e diante de acontecimentos como "Grand Tour". Fuster (1978) ainda faz alusão ao primeiro registro de uso do termo no hebraico, na bíblia, em que Moisés envia um grupo para visitar Canaã e volta para informar sobre condições topológicas, demográficas e agrícolas.

Esse processo de retrospectiva dos conceitos, chegando ao ápice dos símbolos antrópicos comunicador, a palavra, é que (re)orienta os primeiros significados e passos no caminho da desconstrução de uma história linear rumo a (re)associação de uma episteme fragmentada.

(Re)encontra-se na obra Fuster (1978), sobre a égide do núcleo do deslocar-se para encontrar um outro e voltar, a razão fundamental do espaço/tempo do turismo (pg.38): deslocamento cíclico (viagem) + permanência temporária (hospedagem). Ainda nesse viés, Fuster aponta uma sistematização das correntes turísticas, que se compararmos com a futura proposição sistêmica de turismo de Leiper (1979), hoje tida como uma das mais usadas em turismo (Panosso Neto, 2011), reflete a evolução do rumo teórico conceitual.

Quadro 6 - Evolução do sistema turístico

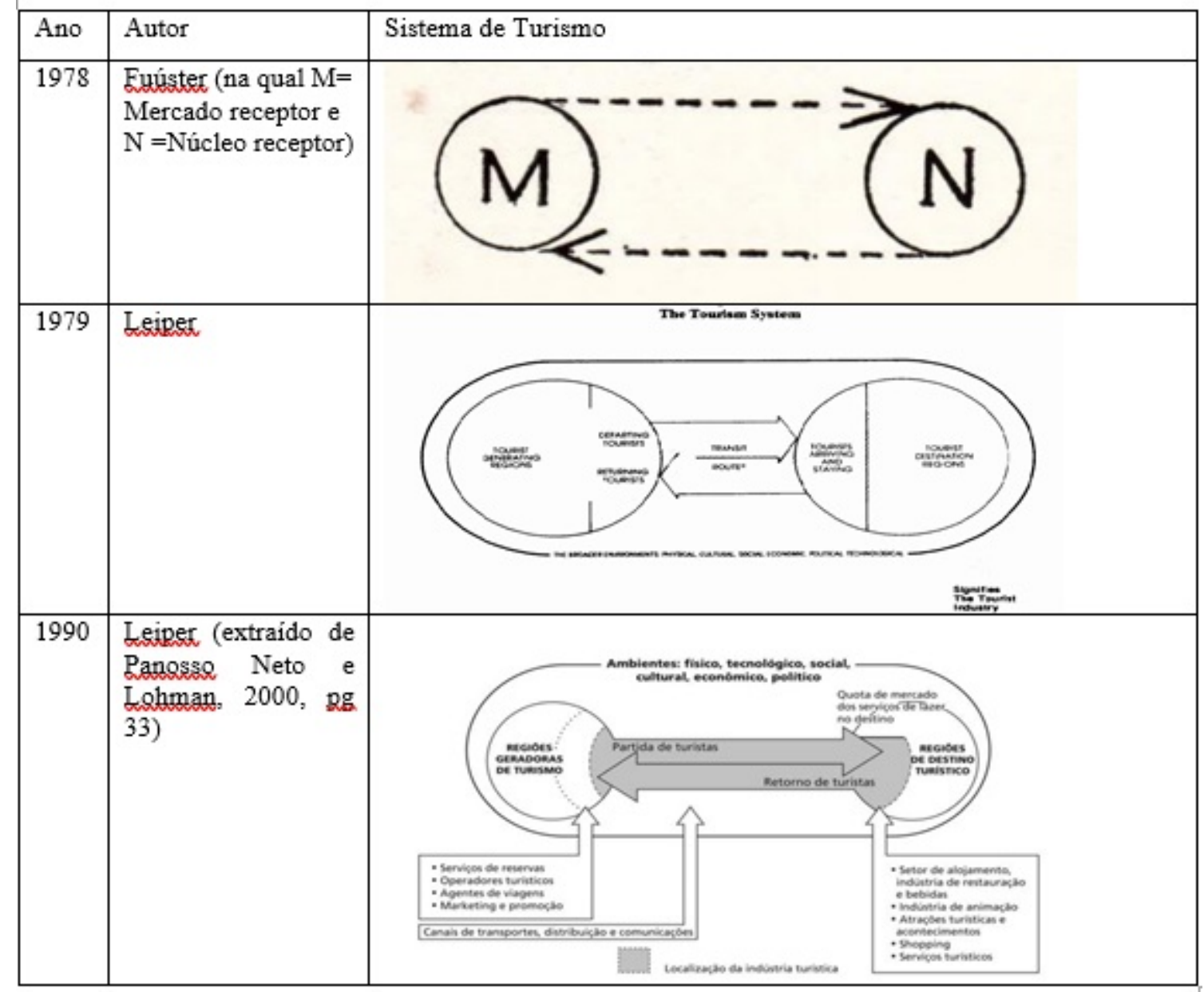

Fonte: Elaboração própria a partir de Fuster (1978), Leiper (1979) e Panosso Neto e Lohman (2000).

Leiper, ao se inspirar na etimologia da palavra turismo (explicitado em 1983), constrói o sistema de referência da atividade até hoje tentando ser replicado e aprimorado (PANOSSO, 2011), mas concebeu 
o mesmo dentro de uma linha prioritariamente econômica e espacial. No Brasil, o sistema de Mário Beni desenvolvido no início dos anos 1990, foi o mais conhecido nacionalmente, mas o mercado também tinha figura central, e o encontro ficou como sub elemento social pouco descritivo. Ainda, sistemas reconhecidos como o de Jafari (1981) e Tribe (1997) apontaram mais as dissonâncias do turismo que um funcionamento coeso, em ambos, o encontro isolados nos estudos específicos da antropologia e sociologia. (Renegado? Ou Renegando? Frase confusa)

Tomando como base os sistemas, conceitos e acontecimentos modernos de turismo, procuramos os saberes arqueológicos aqui revistos: as concepções históricas e etimológicas da palavra turismo, onde estão? O próprio movimento físico temporal, para além do espacial, onde está? Os conceitos de Glucksmann que remetem ao deslocamento e encontro com o outro, onde estão? O conceito de Benschidt, que ao vivenciar a guerra, entende o turismo como paz, onde está? Talvez ainda sobreviva no discurso entusiasta de Krapft, reverberado nas organizações globais, sendo que os fatos empíricos estão colocando em questão o conteúdo desse discurso.

Não se trata de erros ou acertos, como propõe Kuhn (2006), é apenas parte de uma revisão cíclica científica comum e com poder revolucionário. Essa maneira de tratar o turismo pelo viés social não é exatamente uma novidade, talvez justamente se caracterize como uma tendência de retorno teórico e conceitual.

Como sinal dessa possível revisão conceitual, cabe salientar a intenção da OMT ao rever seu conceito de turismo e regressar para o antes criticado termo "fenômeno social". Hall (2005) ao (re)pensar turismo como a mobilidade social e autores nacionais que repensam de forma crítica o turismo (Moesh e Panosso) ganham espaços nas discussões contemporâneas: e o sistema estrutural do turismo mais utilizado no Brasil (elaborado por Beni)sofre pelo próprio autor um repensar a partir da complexidade. Isso conduz a um último exercício "foucaultiano", trata-se de (re)ver as possibilidades, desgrudada da velha norma, frente uma nova ordem estabelecida.

\footnotetext{
"Sob todas essas formas, a coerência assim descoberta desempenha sempre o mesmo papel: mostrar que as contradições imediatamente visíveis não são mais que um reflexo de superfície; e que é preciso reconduzir a um foco único esse jogo de fragmentos dispersos. A contradição é a ilusão de uma unidade que se oculta ou que é ocultada: só tem seu lugar na defasagem existente entre a consciência e o inconsciente, o pensamento e o texto, a idealidade e o corpo contingente da expressão. De qualquer forma, a análise deve suprimir, sempre que possa a contradição”. (FOUCAULT, 1987 pg. 23)
}

\section{POR UM ENCONTRO HABITANTE-VISITANTE}

Assim, o presente estudo se recompõe rumo a uma hipotética (re)aproximação do conceito do turismo com o lado social, sem estripar o lado comercial, mas se propõe a entender as possibilidades que essa nova visão sugere. Apenas como um primeiro passo, não se pretende reconstruir de imediato e por completo todo destino do corpo de análise do turismo, mas sim abrir a porta de um caminho.

Ao pensar sobre o mais recente conceito sugerido da OMT (PACKMAN, 2014), justamente por apontar um "retorno" (literalmente, ao lembrar-se da mesma raiz da palavra turismo), resgatando o esboço de corrente turística de Fuster (1978) e incluindo o carácter temporal e social, parte das características da escola Berlinense e etimológicas do turismo, e assumindo que uma atividade complexa desse calibre não poderia haver um conceito geral sem ser amplo, permeia um entendimento que o turismo é um fenômeno físicosocial, que associa o formato de movimento helicoidal, espacialmente circular e temporalmente linear, ao conjunto de relações pacíficas derivadas do encontro entre habitantes e visitantes.

Assim, o turismo fica resumido na associação de uma dobra física e social pontual, formando um interstício socioespacial único. Essa trama específica só teria uma delimitação quanto ao propósito do tipo de relacionamento, o pacífico, entendendo o tecido formado por uma ação declaradamente bélica como distante ao opor a concepção, ao menos imediata, da intenção de construção/destruição. A derivação das relações entre habitantes e visitados inclui um termo que dá motivo principal ao conhecer o "outro lado", mas ao mesmo tempo abarca outros encontros como visitante-visitante. Por fim, a opção de manter o 
conceito antropológico "Habitante" e "Visitante", justamente por incorporar a ideia de habitat e hábito, aquilo que foge do seu habitar comum rumo a um habitar estranho (aproximando-se do conceito etimológico de experiência).

De forma complementar ao esforço de entender o fenômeno turístico frente às outras áreas do saber, cabe considerar que essa conexão física e social legitima as categorias de análise da geografia humana e história social, respectivamente espaço e tempo social como ótica e categorias que permitiriam a visão do turismo, justamente por fazerem essa associação. Tendo o movimento como físico e a trama como social, aliado ao caráter transdisciplinar, a composição desses campos, do nano aometa, poderia ser representada, conforme a seguir.

Quadro 7 - Dimensões, áreas do conhecimento e representações do turismo

\begin{tabular}{|c|c|c|c|c|}
\hline NANO & MICRO & MESO & MACRO & META \\
\hline Psicologia & Antropologia & Sociologia & Comunicação & Biologia \\
\hline $\begin{array}{l}\text { Relações } \\
\text { humanas, } \\
\text { comunicação } \\
\text { interpessoal. }\end{array}$ & $\begin{array}{l}\text { Relação } \\
\text { habitantes e } \\
\text { visitantes, } \\
\text { processo de } \\
\text { troca cultural. }\end{array}$ & $\begin{array}{l}\text { Relações entre } \\
\text { sociedades, } \\
\text { com processos } \\
\text { de troca socio- } \\
\text { econômicos. }\end{array}$ & $\begin{array}{l}\text { Conexões entre } \\
\text { núcleos } \\
\text { emissores e } \\
\text { receptores, } \\
\text { construção de } \\
\text { redes. }\end{array}$ & $\begin{array}{l}\text { Sistemas em } \\
\text { cadeia, ênfase } \\
\text { formaçãoe } \\
\text { reprodução } \\
\text { genética, como } \\
\text { um formato e } \\
\text { função de } \\
\text { DNA. }\end{array}$ \\
\hline
\end{tabular}

Fonte: Elaboração própria.

Nos campos meso e micro, onde o turismo recebe sua forma comumente "observável", diretamente ligado ao contexto sócio antropológico, merecem uma ilustração diagramada ampliada, caracterizados, conforme a seguir.

Diagrama 1 - Panorama micro e meso do turismo

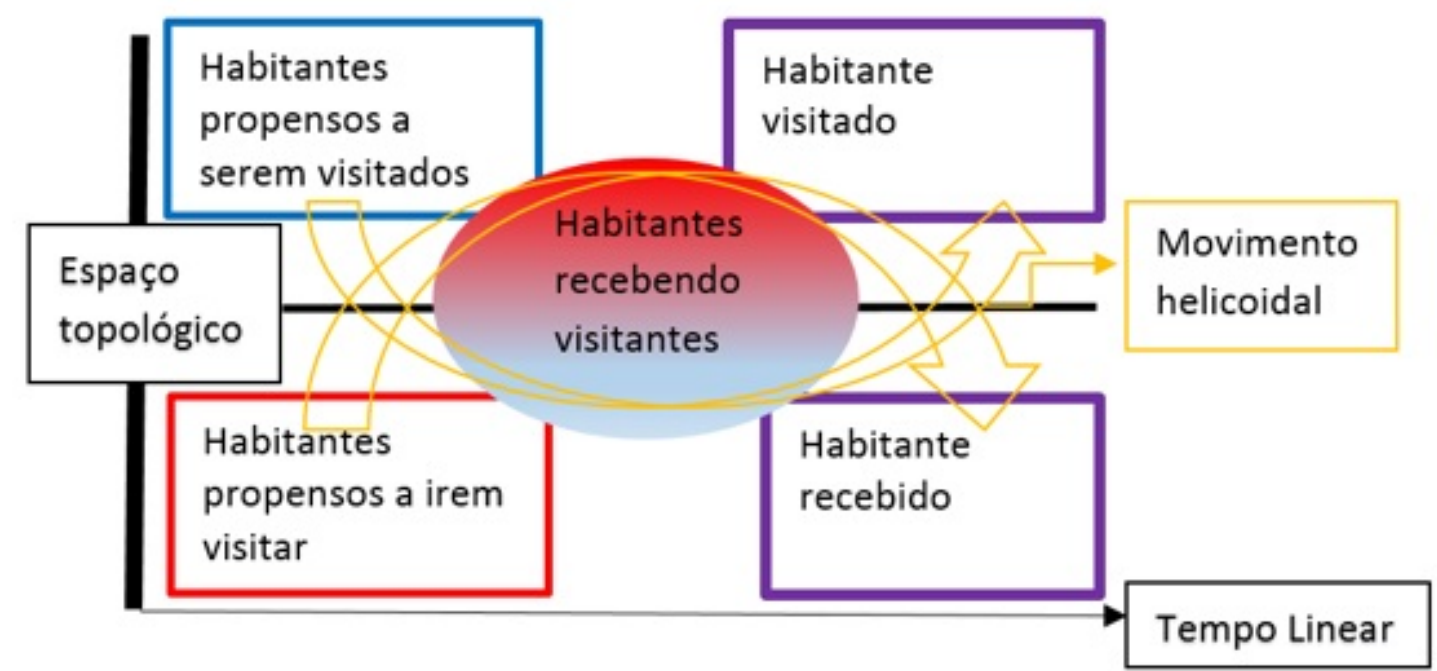

Fonte: Elaboração própria.

O presente diagrama, ainda longe de ser um completo sistema turístico, auxilia no caminho a trilhar. Respeitando e ilustrando a conceituação proposta, indica o ápice do turismo no encontro, mas não como processo inicial, menos como final, as cores funcionam como uma analogia dessa relação. É transformadora 
para ambos os lados, talvez em maior ou menor grau, ainda assim, um fecho de luz possui diversos gradientes de cor, em um continuum, que se liga às cores vermelha e azul, não opostas ou excludentes, que estão no mesmo eixo, representando uma conexão, mesmo que mínima e temporal. Os quadrantes todos tocam no interstício do encontro, mostrando que o habitual de um e do outro devem se tocar, ao menos para fornecer o acesso ao outro lado.

Chega-se na questão: de que forma, efetivamente, esse conceito traz mudanças no paradigma do turismo e harmonizando os paradoxos rumo às novas possibilidades do turismo? Começa ao analisar que os problemas detectados e comentados, pensado a partir de uma analogia da estrutura meta biológica sugerida no quadro 7. O turista como uma faixa de DNA e o residente como a outra faixa de DNA, se o turista for pensado isolado e na vertente econômica, estaria planejado como um RNA viral, que com a função de consumir e (re)produzir busca acoplar sua faixa de RNA em hospedeiros que tem seu código transformado e forçadamente (re)adaptados para continuar seguindo a ordem viral. Se planejarmos o turismo como a junção de turistas e residentes, passaríamos para uma estrutura orgânica mais harmônica, que não teria como função colonizar e transformar outros códigos genéticos e sim evoluir preservando seus laços.

Em primeira análise a aproximação do conceito de turismo rumo a um conceito sociológico, proposta central do presente estudo, significaria transpassar os estudos da antropologia do turismo e sociologia do turismo rumo a um conceito social de turismo. Mudando as bases e abordagens do gênero para o setor.

Isso porque é observado em clássicos da sociologia do turismo (KRIPPENDORF, 2001) e antropologia do turismo (SANTANA, 2009), que o turismo é assumido como fenômeno social para legitimar suas análises, mas ainda sim transparece no decorrer da construção como um fenômeno de turistas/mercadores, o econômico reinventado na pós-modernidade. Por exemplo, o sistema de turismo proposto por Krippendorf (2001) tem mérito por centralizar o humano, no entanto o coloca apenas como o ser "visitante" no centro, sendo que o ser "visitado" continua renegado a coadjuvante de um processo que deveria/poderia ser mútuo.

Santana (2009), ao reconstruir os estudos da antropologia do turismo, relata que, em 1947, houve um primeiro encontro de antropólogos para versar sobre os impactos do turismo, com a conclusão de que são negativos. Revisado, décadas depois, e, ainda reafirmando os impactos como geralmente negativos, apesar de o problema não ser o turismo em si, a condução da atividade turística na sociedade pós-moderna seria o problema da atividade. Em ambos os casos, a visão de turismo resume-se ao turista e o residente continuamente como papel de coadjuvante e passivo na atividade.

Em última análise, Ross (2002), na psicologia do turismo, também apresenta o turismo vinculado como o turista prioritariamente, o pouco que tange ao residente é realizado de forma objetiva ao analisar fatores que formam a aceitação do residente frente ao turista, área essa predileta pela área da gestão (se comparado aos estudos antropológicos e sociológicos) por propor ações diretas de aceitação e controle da comunidade local.

O presente estudo vem justamente propor esse outro olhar perpassando os impactos sofridos pelos residentes até os residentes integralmente como parte do conceito de turismo. Assim, como sugere o conceito etimológico, os primeiros acadêmicos da área e, principalmente, recentemente, o turismo vem sendo (re)pensado por alguns autores e organizações globais.

Em virtude do que foi mencionado, nesse proposto caminho o primeiro passo seria a OMT, como organização global vinculado a $\mathrm{ONU}$, iniciar da mesma forma que faz pesquisas estatísticas para medir o número de turistas e economia gerada, fazer também pesquisas sobre a percepção socioambiental dos residentes, dos que recebem turistas e dos que planejam receber, medindo de forma plena o processo turístico. Hoje, as formas de enaltecer o turismo responsável são as campanhas globais solicitando maior responsabilidade de turistas e divulgando seus casos de sucesso. Mas onde estão os densos estudos estatísticos com direito a séries históricas e levantamento global, na percepção dos residentes, frente aos principais projetos turísticos do mundo? Esse posicionamento unilateral gera planejamentos unilaterais e voltamos à analogia do vírus que implanta, insensivelmente, sua metade do código no hospedeiro. 
Da mesma forma, transformaria os programas nacionais de desenvolvimento turístico, como exemplo consta no anual do programa de regionalização do turismo de 2007 , que a primeira parte do manual é a sensibilização do destino turístico. Essa sensibilização aparenta muito mais uma anestesia da comunidade frente à chegada de turistas que um processo mútuo de aceitação. Mais uma vez, esse manual aponta o econômico como grande benefício, preponderante a qualquer outro impacto negativo ou positivo, social ou ambiental. Irremediavelmente, volta-se para a analogia do vírus, esses manuais seriam um analgésico desenvolvido pelo próprio vírus, justamente para tornar a penetração no hospedeiro indolor com um discurso que o sistema de (re)produção a ser implantado é melhor e que,de certa forma, seu código anterior, dentro do limite, será melhor preservado.

Levando-se em consideração esses aspectos, para não fechar sem uma proposta de ação, aponta-se como formas de (re)pensar e consequentemente planejar a atividade turística pelo viés do residente. Primeiro com o entendimento de quem é aquela possível comunidade receptora, quais os benéficos e malefícios sociais daquela comunidade ao receber determinado tipo de turista. Projetando os possíveis encontros que seriam de interesse mútuo, mediando as formas de aproximação e de troca. O encontro e transformação do código do turista e do residente não assumiria mais a forma de um vírus se hospedando e colonizando um hospedeiro, passaria para a forma de dois gametas, o gameta residente (fêmea) e o gameta turista (macho), formando uma nova vida, mas respeitando suas gêneses.

Em casos em que o turismo já esteja implantado de forma predatória, as capacidades de carga ambiental e social teriam que ser revistas, junto com o fortalecimento do tecido social, reservando espaços de interesse social e de resgate da história social daquela comunidade. Dentro dos passos para um turismo melhor elucidado, Krippendorf (2001) concebeu como legítimo escape os "não lugares", contrapostos a experiências autênticas, serviriam de plataformas estéreis, sem contato e sem avançar rumo a comunidades residentes, atrativos desenhados isolados e longe da trama social. Seria como uma boneca sem vida, destinado ao vírus/ turista que iriam depositar seu RNA em uma pseudo-localidade, infértil e sem vida, assim com menos propagação de impactos ao mesmo tempo em que supre a ânsia pelo consumo e (re)produção.

\section{CONSIDERAÇÕES FINAIS}

A pesquisa segue a política científica, em constante revolução prática/conceitual, na qual os mundos, metafísico e real, se retroalimentam intermediados pelo mundo do homem. Nesse panorama de repensar a atividade turística, a teoria, como reflexo da prática, apresenta abstrações que permitem a condução por novas possibilidades.

O presente estudo avança no processo de repensar o turismo ao analisar os problemas dos desdobramentos teóricos e empíricos dos conceitos normatizados sobre uma égide que exclui o encontro habitante-visitante, convergindo na posição de outros autores de que esse é um ponto chave que deve ser revisto, bem comopropondo um caminho teórico conceitual a seguir.

Por ter um caráter predominantemente ensaístico e teórico, crítica ao modelo vigente, e rumo a uma nova concepção que aponta um caminho a seguir, justamente nesse último ponto que se limita, abrindo perspectivas de pesquisas futuras que possam alavancar mais discussóes e apontamentos sobre esse conceito insurgente.

\section{ReFERENCIAS}

ALMEIDA-GARCÍA, PELAEZ-FERNANDEZ, BABUENA-VÁSQUEZ \& CORTÉS-MARCIAS. Residents' perceptions of tourism development in Benalmadena (Spain). Tourism Management, 54, 259-274. 2016.

BARRETO, M. Relações entre Visitantes e Visitados: um retrospecto dos estudos Socioantropológicos. Turismo em Análise, v. 15, n. 2, p. 133-149, novembro. 2004 
BENI, M. C. Análise estrutural do turismo. 8. ed. São Paulo: Senac. 2001.

BRASIL. Programa de regionalização do turismo. Brasília: Ministério do Turismo. 2007

BRASIL. Documento Referencial de Turismo no Brasil Turismo no Brasil - 2011/ 2014. Brasília: Ministério do Turismo. 2010.

BRASIL, Ministério da Educação. http://portal.inep.gov.br/basica-censo-escolar-sinopse-sinopse acessado em 09/05/2015. 2015.

COHEN, E. Traditions in the qualitative sociology of tourism. Annals of Tourism Research, Vol. 15, pp. 29-46. 1988

DOXEY, J. Development of tourism destinations. London: Torbay. 1975

FOUCAULT, M. A arqueologia do saber. Rio de Janeiro: Florence. 1987

FOUCAULT, M. As palavras e as coisas: uma arqueologia das ciências humanas. Martins Fontes: São Paulo. 2000 FERNADEZ FUSTER, L. Teoria y Tecnica del Turismo. Madrid: Nacional . Vol. I. .1978

GALLARZA, M. G., GARCIA, H. C. \& SAURA, I. G. Destination image: towards a conceptual framework. Annals of Tourism Research, vol. 29, n. 1, p. 56-78. 2002.

GRAY, P. Tourism theory and practice, a reply to Albert Sessa. Rejoiders and commentary. Annals of Tourism Research. 1983.

HALL, C. M. Turismo como la ciência social de la movilidad. Sitesis: Madrid. 2005.

HUH, C., \& VOGT, C. A. Changes in residents' attitudes toward tourism over time: a cohort analytical approach. Journal of Travel Research, 46, 446e455. 2008.

INSTITUTO DE PESQUISA DATA FOLHA. Imagens dos estrangeiros sobre a Copa do Mundo. Disponível em http://www1.folha.uol.com.br/poder/2014/07/1486012-organizacao-da-copa-e-bem-avaliadapor-83-dos-estrangeiros.shtml. 2014

KRIPPENDORF, J. Sociologia do turismo: para uma nova compreensão do lazer e das viagens. Rio de Janeiro: Civilização Brasileira. Edição comemorativa 25 anos, revisada e ampliada. 2009.

KUNH, T. S. A estrutura das revoluções científicas. 9. ed. São Paulo: Perspectiva. 2006

JAFARI, J. \& RITCHIE, J. R. B. Toward a framework for tourism education: problems and prospects. Annals of Tourism Research, v. 8, n. 1 p. 13-34. 1981

JAFARI, J. La cientifización del turismo. Estudios y Perspectivas en Turismo, Buenos Aires, Ciet, v. 3, n. 1, p. 7-37. Jan. 1994.

LEIPER, N. The Framework of Tourism: Towards a Definition of Tourism, Tourist,and the Tourist Industry. Annals of Tourism Research, vol 6, p. 390-407. 1979. . An Etimology of "Tourism”. Annals of Tourism Research. vol 10, p. 277-281. 1983.

MACCANNELL, D. El Turista, uma neuva teoria de la clase ociosa. Barcelona: Ed. Melusina, 2003.

MILITO, M. C., MARQUES JR. \& LEMUEL, M. A. Percepção do residente em relação a turismo e megaevento: análise bibliométrica de periódicos internacionais e latino-americanos. Revista Turismo em Análise. V. 24, №3, pp.482- 502. 2013

MILITO, M. C. Fatores que influenciam o apoio de residentes á megaeventos: um estudo sobre a FIFA WORLD CUP 2014 em Natal-RN. Dissertação de mestrado defendida no Programa de Pós Graduação em Turismo, UFRN. 2013.

MOESCH, M. A Produção Do Saber Turístico. São Paulo: Contexto. 2000.

MORIN, E; LE MOIGNE, J. A inteligência da complexidade. São Paulo: Peirópolis. 2000

OMT. Introdução ao turismo. São Paulo: Rocca. 2001.

PANOSSO NETTO, A. Filosofia do Turismo: teoria e epistemologia. São Paulo: Aleph. 2005.

PANOSSO NETTO; NECHAR, M. C. Epistemologia do turismo: escolas teóricas e proposta crítica. In: Revista Brasileira de pesquisa em Turismo. São Paulo, 8 (1), pp. 120-144, jan/março. 2014. 
PANOSSO NETTO, A. E LOHMAN, G. Teoria do Turismo: conceitos, modelos e sistemas. Aleph: São Paulo. 2000

ROSS, G. Psicologia do turismo. Contexto: São Paulo. 2002

SANTANA, A. Antropologia do turismo: analogias, encontros e relações. Aleph: São Paulo. 2009.

SESSA, A. Comments on Peter Gray's "The contribuition of economic tourism”. Rejoiders and commentary. Annals of tourism Research. 1984.

PACKMAN, E. T. Sobre as Definições de Turismo da OMT: Uma Contribuição à História do Pensamento Turístico. Anais Da Associação De Pesquisa E Pós Graduação Em Turismo. 2014.

TRIBE, J.The indiscipline of tourism. Annals Of Tourism Research, v. 24, n. 4, p. 638-657. 1997.

\section{BY}

